\title{
On the evolution of translations from Serbian into Romanian
}

\author{
Mața ŢARANANDREICI \\ West University of Timişoara, \\ Romania
}

\begin{abstract}
Our paper outlines an updated picture of the translations from Serbian into Romanian, and also points out the most common concepts belonging to the most notorious translators and the specific particularities of their translation manners. The goal of our research is to identify reference points in the evolution of translations, i.e. from theories to methods and procedures of translation. Thus, we intend to evaluate the contribution of some translators as well as to mention some general aspects that characterize their methodology. Among the aspects that we are going to research are the level of adequacy and representativeness of their translations, and the way in which they apply the functional principle of preserving the information from the original.
\end{abstract}

Keywords: concept, translation studies, translation spectrum, interdisciplinarity.

Riassunto: Il presente contributo si propone sia di offrire un quadro aggiornato delle traduzioni dal serbo al romeno, sia di delineare le tendenze dominanti a livello concettuale reperibili nella prassi dei traduttori, nel tentativo di rilevarne le particolarità. La finalità della nostra indagine è quella di registrare le tappe significative dello sviluppo della traduzione, dalle teorie alle strategie e alle tecniche di traduzione. In quest'ottica, la nostra ricerca intende valutare i contributi di alcuni traduttori e di metterne in risalto alcuni aspetti metodologici. Cercheremo di individuare sia il grado di mantenimento dell'adeguatezza e della rappresentatività del testo da tradurre, sia le modalità di applicazione del principio di funzionalità alla conservazione delle informazioni ivi contenute.

Parole-chiave: concetto, traduttologia, spettro traduttologico, interdisciplinarità.

\section{Introduction}

Translation studies became a science only in the final decades of the $20^{\text {th }}$ century, in direct connection with Semantics and Stylistics (Stojanović 2009, 136). Nevertheless, translation issues had already appeared with the writers of the Antiquity. With reference to the translation process, Demostene and Cicero noticed that it was impossible to match each Greek word with a Latin word and that the number of words was not the most important matter, but their signification and their gravity. Half a century later, Horatius stated this idea again, his advice for translators being to avoid word by word translation (Revzin 1964, 6). Moreover, it is a well-known fact that 
creative processing was a standing feature of translations into Latin, with texts being adapted in order to fit the aesthetic criteria of the Romans.

Until the $16^{\text {th }}$ century, $80 \%$ of the books published in Europe were in Latin. Between the $16^{\text {th }}$ and the $18^{\text {th }}$ centuries, Spanish, English and German texts translated into French appeared in France.

During the Renaissance, ideas about translation stated by the writers of the Antiquity became current again. Important men of culture of this remarkable era in mankind's history were confronted with the problem of rendering the "spirit" of the source language literature. Moreover, writers and poets of the Renaissance were interested in creating a national literature, given the context of their activity in the period of the formation of the European nations and their literatures. As a consequence, two main, yet opposite concepts in the practice of translation coexisted: the first one was the precise rendering of the original linguistic web, while the second one stated that the only important thing in producing a translation is to convey the meaning and the spirit of the original.

A representative translator for the first concept was the $15^{\text {th }}$ century German translator Niklaus von Wyle, author of a translation study in which he demanded the rendering of each Latin grammatical construction. On the other hand, in the same period, when translating the Bible into German, Martin Luther chose to translate in the spirit of the German language, so that many people considered him to be the creator of the current German prose.

The tendency to do accurate translations which correspond to the target language norms may be seen with all theoreticians of the $16^{\text {th }}$ century. An illustrative study of this idea is the paper De la manière de bien traduire d'une langue en l'autre written in 1540 by the French humanist Etienne Dolet. However, he approaches the process of translation from an aesthetical point of view, considering that translation and literary translation are one and the same thing.

Such an approach to the translation process generated doubts regarding translatability, doubts stated by Dante back in the 15th century: "Nothing that the muses harmoniously create can be rendered from a language into another without destroying its charm" (Revzin, 8).

For $17^{\text {th }}$ and $18^{\text {th }}$ centuries French and English writers, who imposed severe aesthetical norms to literature, translation is allowed only in accordance with literary and linguistic norms of the $17^{\text {th }}$ and $18^{\text {th }}$ centuries. It is no coincidence that The Iliad was translated into French only in 1681 and that the translation made a century later in a shorter form carries the remarkable notice of the translator: "I had to replace some ideas that were enjoyable in Homer's period with ideas that people enjoy today" (Mounin 1955, 90).

When evaluating a translation from an aesthetical point of view, the linguistic aspect is almost neglected: the translator only has to 
adapt the text to a dominant aesthetic principle. Even a progressive writer such as Voltaire failed to grasp the spirit of the ancient literature:

I am convinced that we have two or three poets in France capable of translating Homer excellently, but, at the same time, I am firmly convinced that their works will not be read, unless they simplify almost everything. The explanation is that you have to write for today and not for the old times (Moldovan 2000, 9).

Another tendency in opposition with the one supported by the French classicism appeared in Europe at the end of the $18^{\text {th }}$ century the beginning of the $19^{\text {th }}$ century together with the attempts of the Romantic writers to convey the spirit of the source language culture. Some Russian writers also assimilated this principle, even though some of them interpreted the original in a personal manner, as Derjavin. Others, such as Pushkin, tried to apply the frame of the Russian mentalities over the particularities of the original texts.

All these translators took into consideration the problems of translating literary texts. The activity of translating scientific papers which created scientific terminology - was practically undiscussed by the theoreticians of translation. Therefore, despite the fact that the interest in practical problems of translation constantly grew, actual theoretical studies were lacking: translation was considered to be an act of art and was approached from an aesthetic point of view until the end of the $20^{\text {th }}$ century.

In the $20^{\text {th }}$ century, translations that were outside the sphere of literature, such as technical, legal or military translations, gained a great importance. Without them, the evolution of science and the international intercultural relationships nowadays could not happen. The amplitude and the great importance of the translation activity required a generalization and systematization of the huge experience gained by translators by now and the normalization of the practice of translation (Fjodorov 1983, 15). The science that had the mission to do this and became a distinctive branch of Linguistics is Translation Studies.

\section{Our Study}

In the $20^{\text {th }}$ century, century in which international relations, economic and cultural exchanges amplified remarkably, also named the century of translations, the need to systematize theoretical acquisitions in the field became visible and along with it the methodological principles and procedures that had been used throughout the centuries in the process of translation. This is the context in which the first literary translation from Serbian into Romanian and from Romanian into Serbian appeared. Nevertheless, the tradition of cultural exchanges reflected in translation from Serbian into Romanian and from 
Romanian into Serbian is much older than that. For instance, at the middle of the $19^{\text {th }}$ century, the first Romanian translations from the Serbian folklore appeared. Translations of Serbian folk poems done by George Sion from Bukovina, in 1861, published in Revista Carpaților, or Dionisie Miron, a writer from the Banat region who translated a version of the ballad Deplângerea soției lui Asan-Aga/Hasanaginica [The Mourning Song of the Noble Wife of Hasan Aga/Hasanaginica], published in B. P. Hasdeu's newspaper Traian, are two examples in point. Due to the stormy history of the Balkans in the first half of the last century, marked by the First World War, literary translations appeared only in the 1930's. Some of the first translations from Serbian into Romanian were Jovan Dučić's Blago cara Radovana/ Comoara Impăratului Radovan [Tsar Radovan's treasure] and Gradovi $i$ himere/ Cetăți și himere [Cities and chimeras] translated by Bogoljub Pisarov, while the first translation from Romanian into Serbian was Liviu Rebreanu's Ciuleandra/Ćuljandra [Ciuleandra] translated by Vl. Maksimović.

In the last decades this activity intensified, many works of Romanian literature being translated into the language of the neighboring country: Liviu Rebreanu's novel Răscoala/Buna [The Uprising] translated by Stevan Milović, Mihail Sadoveanu's Baltagul/Osveta [The Hatchet] translated by Aurel Gavrilov, Nichita Stănescu's cycle of poems Belgradul în cinci prieteni/Beograd u pet prijatelja [Five Friends in Belgrade] translated by Adam Puslojić, Lucian Blaga's Linia vieții mele/ Linija mog života [The Line of my Life] translated by Adam Puslojić, Mihai Eminescu's Opere alese/Izbrana dela [Selected works] translated by Ioan Flora and Octavia Nedelcu, Eugen Simion's Demonul teoriei a obosit/Umoran je demon teorije [The demon of theory is tired today] translated by Adam Puslojić. Translations of the Serbian prose, poetry and dramaturgy works into Romanian are more numerous, for example Branislav Nušić's play Gospođa ministarka/Doamna ministru [The Minister's Wife] translated by Mirko Jivcovici, Nobel laureate Ivo Andrić's novel Na Drini ćuprija/E un pod pe Drina [The Bridge on the Drina] translated by Gellu Naum and Ioana G. Seber, Miloš Crnjanski's novel Seobe/ Migrațiile [Migrations] translated by Dușan Baiski and Octavia Nedelcu, Miodrag Bulatović's novel Ljubavnik smrti/Amantul morții [Death's Lover] translated by Mariana Ștefănescu, Milorad Pavić's Unutrašnja strana vetra ili roman o Heri i Leandru/Partea lăuntrică a vântului sau roman despre Hero și Leandru [Inner Side of the Wind or a Novel of Hero and Leander] translated by Simeon Lăzăreanu and many others.

In the $20^{\text {th }}$ century translations of Dositej Obradović's works and of some folk epic poems prevailed. Some other authors whose works were translated in the period are: Laza Lazarević, Ivo Vojnović, Bora Stanković, Iovan Dučić. One may notice that the number of the 
Serbian authors whose works have been translated into Romanian is relatively small. It seems translators carefully choose the works that were really representative for the Serbian modern literature. The following works were translated by more translators: Laza Lazarević's Školska ikona [The School Icon]', Srpske pripovetke [Serbian Fairy Tales ${ }^{2}$, Verter [Verter $] 3$. The first translation is characterized by the "folk" style, sometimes strained, yet by the authenticity of dialogue. The translation of the short-story Werther is also of a good quality. Although it appeared in a volume of popular works, its author placed it on the same level as many Western authors. An expert of the Serbian language and literature, Lazarević, as N. Batzaria, the author of the preface stated, gives the impression of a Western writer. Chronologically, they are followed by the translation of Ivo Vojnović's work Sirene [Maraid] 4 , translation that faithfully renders linguistic and stylistic features of the original.

A few years later Bogoliub Pisarov's translations came to light. The work that he firstly translated was Blago cara Radovana [Tsar Radovan's treasure $]^{5}$ written by Jovan Dučić, Serbian ambassador to Romania. It is followed by Gradovi i himere [Cities and chimeras] ${ }^{6}$ and Plave legende [Blue Legends]7. However, Pisarov was neither a writer, nor a poet, and thus he did not dare to translate Dučićs elegant lines too. Translations that Pisarov did are of a good quality. Moreover, his whole activity made a significant contribution to the popularization of Serbian literature in the inter-war period.

In 1954, once Branislav Nušić's play Gospođa ministarka [The Minister's Wife $]^{8}$ was translated into Romanian, a prosperous period began for the translation between the two languages, Serbian and Romanian. This process was facilitated by the general cultural climate of that time in Europe, ripe with translations. Works in prose, especially novels were translated; works of other genres, such as shortstory, drama and poetry, were not yet in a substantial amount.

${ }^{1}$ Lazarovici, Lazăr. Popa nostru ăl bătrân. Translated by N. Ținc, Slatina: Tip. şi Legătoria de cărţi C. Constantinescu 1911, 60 p.

${ }^{2}$ Lazarevici, Lazăr. Povestiri sârbești. Translated by V. Teconția, București, 1916.

3 Lazarevici, Lazăr. Werther. Translated by C. S. Constante, București: Adevărul, 1926.

4 Vojnović, Ivo. Sirena. Translated by Ion Gorun, București: Adevărul, 1925.

5 Ducici, Iovan. Comoara Impăratului Radovan. Cartea despre soartă. Translated by B. Pisarov, București: Tipografia ziarului „Universul”, 1938.

6 Ducici, Iovan. Cetăți și himere. Srisori din St. Beatenberg, Geneva, Paris, Corfu, Roma, Delphi, Avila, Atena și Ierusalim. Translated by B. Pisarov, București: Tipogr. „Cugetarea”, P.C. Georgescu-Delafras, 1939.

7 Ducici, Iovan. Legende albastre. Poeme în proză. Translated by B. Pisarov, București: Tipogr. „Cugetarea”, P.C. Georgescu-Delafras, 1939.

8 Nušić, Branislav. Doamna ministru. Comedie în patru acte. Translated by Mirco Jivcovici, București: ESPLA, 1954. 
Taking into consideration all the translations of Serbian literature after the Second World War, one may notice that, most often, works have been translated in accordance with a national hierarchy of values. Examples are many, but we cannot leave aside Dușan Baiski and Octavia Nedelcu's translation of Miloš Crnjanski's novel Seobe [Migrations] 9 , a faithful version of the original which preserves its stylistic quality, uses a rich picturesque lexicon and reproduces in a great measure the expressivity of the original. However, comparing some of the Serbian chapters of this work translated into Romanian with their Romanian, Cornel Ungureanu notices that the "original phrase is even more dense, more quivering, expressing through its endless sinuosity a more violent vitality, a more restraining grip of the world, of disease, of death" (Ungureanu 1993, 206).

Important translations of this period were the translations of Ivo Andrić's literary works $\mathrm{Na}$ Drini ćuprija [The Bridge on the Drina $]^{10}$ translated by Gellu Naum and Ioana G. Seber Bosnian, Travnička hronika [Bosnian Chronicle or Chronicles of Travnik] ${ }^{11}$, and the collection of poems Priča o vezirovom slonu [The Story of the Vizier's Elephant $]^{12}$.

As far as poetry is concerned, fewer works were translated. Most of the translations of Serbian poems into Romanian have been published in Orizont magazine from Timișoara, but also in Luceafărul, Secolul XX, and România Literară magazines. The only Serbian poet that has an entire book of poems translated into Romanian is Vasko Popa. The quality of the translation is ensured by the name and the reputation of the translator, Nichita Stănescu, himself a great poet, familiar with Serbian feelings and mentality. As he was both well versed in the Serbian language and an expert in using the expressivity of the Romanian language, the translator made every effort to keep the translation faithful to the original, including versification features and other elements of expressivity found in the original. Hence, he succeeded in keeping the rhythm and the melodicism, as well as the style of the original. To overcome the difficulty of maintaining prosody, the author uses lexical prosthesis, usually monosyllabic words. Monosyllabic words are also used in order to preserve the rhyme. This procedure sometimes affects the word order, a fact that demonstrates once more that the most difficult task to fulfil during the translation of

9 Crnjanski, Miloš. Migrațiile, Translated by Dușan Baiski and Octavia Nedelcu, Timișoara: Editura de Vest, 1993.

10 Andrić, Ivo. E un pod pe Drina, Translated from french by Gellu Naum and Ioana G. Serber, București, Editura pentru Literatură Universală, 1962.

11 Andrić, Ivo. Cronica din Travnic. Viziri şi consuli. Translated by Virgil Teodorescu și Dragan Stoianovici, București: Editura pentru Literatură Universală, 1967.

12 Andrić, Ivo. Povestea cu elefantul vezirului. Translated by Gellu Naum and Voislava Stoianovici, București: Editura pentru Literatură Universală, 1966. 
poetry is to render the very features that endow it with great stylistic value. There are two main ways of translating poetry: to create in the target language a work that challenges the original or, even more, exceeds it, or to faithfully stick to the message and the semantics of the original and to make a work that not always preserves the artistic geniality of its author. The middle path between these methods seems to be the best variant.

The incontestable difficulty of translating poetry did not prevent Romanian translators from translating representative poems by Serbian poets, even when the authors were considered to be untranslatable. Although we cannot talk about absolute equivalences in this field, the process of translating poetry persisted. Generally, the translators look forward to being faithful to the spirit of the original and not its letter, although they are quite keen on preserving some expressive details rendering them by different expressive means of the target language. However, the translation should accurately render the subjectivity of the author, which means that in a translation, the voices of the both the original author and translator should be heard.

The echo of the literature of the nations from former Yugoslavia in the second half of the $20^{\text {th }}$ century proves the growing interest in Serbian literature. Hence, there have been approximately three thousand books translated in more than forty countries, of the five continents, during a period of half a century.

The roots of translations of Yugoslavian literature into Romanian lay in the activity that the members of the Department of Slavic Languages from the University of Bucharest had started in 1949. They were Mirco Jivcovici, Dorin Gămulescu, Voislava Stoianovici, and Victor Vescu. One of the particularities of these efforts was the fact that the translations were done by two translators, one of them being a writer in the target language (Nedelcu 2012, 177-184). The latter was not necessarily supposed to know the source language and his/her function was to make the translation sound more artistic in the target language, although this may affect the content and, consequently, the value of the translation. The risk that exists in such cases is that translations of works belonging to different authors that obviously have different styles or even belong to different genres may have the same style in the target language as they are adjusted by the same person. Therefore, for example, one can notice in the Romanian translation of the well-known Serbian work Bosnian Chronicle (or Chronicles of Travnik) stylistic features that are not particular to Andrićs style.

The graduates of the program mentioned above and some Romanian students from Yugoslavia, who graduated from the University of Bucharest, formed a new generation of translators. On that account, a wave of intercultural change starts to appear and more than a hundred volumes of literary works representative for Yugoslavian literature are translated into Romanian. There have also 
been Romanian literary works translated into Serbian, more than two hundred volumes of classical and modern literature since 1950 up to the present, some of them of a great value.

After the 1989 Revolution a new picture began to shape up in the field of translations. The disappearance of censorship and privatization facilitated an explosion of the editorial activity. There are mainly translated works by dissident writers, by exiled writers, or religious literature. Similarly, works by writers from the former Yugoslavia that became popular in the West stir a great interest, such as Ivo Andrić, Milorad Pavić, Miloš Crnjanski, Danilo Kiš. Furthermore, the financial criteria take over now, even if it does not always fit the quality criterion, as the selection is made based on economic competition.

Translations are most of the time accompanied by prefaces, afterwords, biographical notes, texts that are valuable bibliographical sources. Most often, they describe the content and the style of the work itself with no reference to the particularities or the quality of the translation. Hence, they are descriptive, the normative intention being implicit. No research or translation study regarding the translations from Serbian into Romanian has been published until now.

Contrary to Western Europe, where national cultural hegemony in France and Romantic faithfulness to the original in Germany have been imposed as principles of translation, in Romania translations present some other dimensions also, such as the political (or ethic) principle and the linguistic (or aesthetic) principle. However, the measure to which they are followed varies from a translator to another ${ }^{13}$ and is determined by the relevant temporal gap that exists between choices made by Western European and Romanian translators.

Translations that have been made from Serbian into Romanian observe the fundamental concepts of translation. These are the functional equivalence (i.e. preserving the global message of the original) and faithfulness, as a proper translation is obtained when the message is decoded from the source language and formulated in the target language. Oscillating between translating the meaning and translating the letter, Romanian translators of Serbian literature consider the faithfulness to be a significant feature of a translation. A translation is made considering a wide array of factors that have to form a symbiosis in order to fulfill the aim of the translating process. The translation method used is included, the subjectivity of the translator, the distance in time between the original and its translation, the culture of the target language and its linguistic possibilities. Translations made from Serbian into Romanian acquaint Romanian literature with Serbian literature values and force Romanian translators

13 More detailed information about the methods of translation and models for translation see Badea, 2014. 
to search for equivalent terms and proper phrases in order to adequately render the message of the original text. Irrespective of the methods used, translations contributed to pointing out the differences between the Serbian and Romanian languages and between the cultures of the two nations. The contact between the two cultures has been facilitated by the press. It was also the mass-media that provided the translators with neologisms. The specificity of the Romanian lexicon forced translators to give up the traditional manner of translation that implied avoiding neologisms and borrowings, and to start using the language the current speakers of the Romanian language use.

Translations from Serbian into Romanian are included in the international heritage of cultural works, they represent an intersection between tradition and innovation, and they have a formative role for the national culture, as well as an informative role for the individual.

\section{Conclusions}

In conclusion, regardless of the contributions that Romanian theoreticians have had in the field of translation studies, we cannot claim that in Romania theories or schools of translation have been established. Most often, translators refuse to focus on the theory of translation, preferring to focus on its practice. Lack of theory or its refusal also represents a certain theoretical attitude, an attitude which is sometimes more detrimental than an erroneous theory that is declared. The general attitude of translators is uncompromising: they either consider that translating is equivalent to creating and are not satisfied with the role of intermediaries, or they consider themselves simple technicians and underrate their work (Badea 1999, 199-221).

The art of translation is born from this battle between liberalism and absolute freedom while it tries to reveal its secrets.

Given the necessity of a descriptive and diachronic approach to translations from Serbian into Romanian, an aspect only briefly dwelled upon in specialized studies, we consider that the content of the present paper will provide significant insights into the evolution of translation, thus shaping an overview of the translation space under discussion. This overview of translation works represents the basis of future applied studies, of a critical and analytical nature, in view of illustrating the challenges and particularities of the Serbian- Romanian translation space.

\section{References}

Fjodorov, Andrej. Iskusstvo perevoda i žizn' literatury [Art of translation and life of literature]. Leningrad: Sovetskij Pisatel', 1983.

Frajnd, Marta. «Perevod u dijahroniji» [Translation in Diachrony]. In: Krinka, Vidaković-Petrov (ed.). Književno prevođenje. Teorija i istorija [Literary Translation: Theory and History], [Beograd]: Institut za književnost i 
umetnost; Požarevac: Braničevo; [Novi Sad]: Književna zajednica Novog Sada, 1989: 143-150.

Frajnd, Marta. «Procesi prevođenja u dijagonalnom dijahronijskom prevodu» [The Process of Diachronic Translation]. In: Prevodna književnost [Literary Translation]. XIII-XXII. Beograd: Udruženje književnih prevodilaca Srbije, 2001: 32-38.

Hlebec, Boris. Opšta načela prevodjenja [General Principles of Translation], $1^{\text {st }}$ Edition. Beograd: Beogradska knjiga, 2009.

Janićijević, Jovan. «Istorija prevodne književnosti i istorijska poetika prevođenja» [Literary Translation History and Historical Poetics of Translation]. In: Prevodna književnost [Literary Translation]. XXVII-XXVIII. Beograd: Udruženje književnih prevodilaca Srbije, 2002-2003: 97- 103.

Lungu Badea, Georgiana. Idei și metaidei traductive româneşti (secolele XVI$X X I)$ [Romanian ideas and meta-ideas on translation (16th-21th centuries)]. Timişoara: Eurostampa, 2013.

Lungu Badea, Georgiana. «Übersetzungsmethoden im Rumänischen im 18. und 19. JahrhundertPolitische, sprachliche, ethische und ästhetische Problemstellungen.» [Methods of Translation in Romanian Language (18 ${ }^{\text {th }}$ and $19^{\text {th }}$ centuries). Political, Lingvistic, Ethical and Esthetical Issues.]. In: "Traducerile au de cuget să îmblînzească obiceiurile ...” Rumänische Übersetzungsgeschichte - Prozesse. Produkte. Akteure, Berlin: Frank \& Timme, p. 33-6o.

Lungu Badea, Georgiana. «Necesitatea unei critici a traducerii» [The Necessity of Translation Criticism]. In: Analele Universității de Vest din Timișoara. Seria Ştiințe Filologice, [Annals of the West University of Timișoara. Philological Sciencies], (XXXVI-XXXVII): 199-222. Timişoara: Editura Universtității de Vest, 1998-1999.

Mančić, Aleksandra. Prevod i kritika [Translation and Criticism]. Beograd: Institut za književnost i umetnost, 2010.

Moldovan, Valentin. Teoria traducerii artistice [Theory of literary translation]. Timișoara: Eurostampa, 2000.

Mounin, Georges. Les belles Infidèles [Beautiful Infidels]. Paris: Cahiers du Sud (1955).

Nedelcu, Octavia. «Literatura sârbă» [Serbian Literature]. In: Geambașu, Constantin (coord.). Bibliografia traducerilor din literaturile slave [Bibliography of Literary Translations from Slavic Languages] (1945-2011). Bucureşti: Editura Universității din București, 2011, p. 77-89.

Revzin, Isaak, Rozencvejg, Viktor. Osnovy obščego i mašinnogo perevoda [Introduction into General and Machine Translation]. Moskva: Vysšaja Škola, 1964.

Stojanović, Vojislava. Dodiri i prožimanja [Contiguity and Interferation]. Timișoara: Uniunea Scriitorilor români, 2009.

Țaran Andreici, Mața. Introducere în teoria și practica traducerii, aplicată la studiul comparativ al limbilor sârbă şi română [Introduction into the Theory and Practice of Translation Applied to the Comparative Study of Serbian and Romanian Languages]. Timişoara: Editura de Vest, 2014.

Ungureanu, Cornel. «Postfață» [Postface]. In: Crnjanski, Miloš. Migrațiile [Migrations]. Timișoara: Editura de Vest, 1993. 